\title{
The role of Government in Tourism Competitiveness and Tourism Area Life Cycle Model
}

\begin{abstract}
The study investigates the role of government in tourism competitiveness and underlying relationship based on the Tourism Area Life Cycle (TALC) model. The involvement of government in the process of tourism development is somehow crucial, however, this involvement should be controlled. The study uses time-series data and exploits a case study approach to fulfill the overlooked aspect of the tourism industry about the current theme under study. From the selected three countries in the Asia Pacific, the results indicate that China is close to the consolidation stage, India is in between the 'Involvement' and 'Development' stage, and Pakistan is in between the 'Exploration' and 'Involvement' stage, with reference to TALC model. The study concludes that the lower level of government involvement is needed for China, and a higher level of government involvement is needed for India and Pakistan to enhance the level of competitiveness.
\end{abstract}

Key Words: Tourism competitiveness, Sustainability, Role of government, Economic freedom, TALC, Tourism industry, Asia Pacific, China, India, Pakistan

\section{Introduction}

Tourism is a globally and dynamically growing industry. International tourist arrivals showed extraordinary and outstanding growth over the past decade, especially since the 1980s. There were 25 million international tourist arrivals in 1950, exceeded 1200 million by 2017 (UNWTO, 2018). At the same time, tourism is a very complex field with multiple stakeholders and interrelated industries such as airlines, hotels, natural areas, and attractions. This dynamic branch requires cooperation among the private sector, the public sector, and other stakeholders to sustain in the long run (Tučková \& Jurigova, 2014). As a matter of fact, tourism is important in terms of providing employment opportunities, a chance for destination development and economic growth (Andereck, Valetine, Vogt \& Knopf, 2007). However, the tourism industry also faces market distortion (government involvement) and market failure (inefficiency) (Bull, 1995; Michael, 2001; Croes, 2011).

In spite of continued growth in the tourism industry, the role of government is important due to its impact on any national economy and residents' quality of life. In view of this, many authors recognized the same role of government and stressed to consider the institutional environment for better understanding of the tourism development and the outcomes at the country level (Dredge \& Jenkins, 2007; Dredge \& Jamal, 2015; Hall, 2011; Sambharya \& Rasheed, 2015). Since the role of government has evolved over time from economic concerns to socio-cultural, political and environmental aspects which is quite noticeable in developing countries where the role of government in the tourism industry is prominent (Yang, Wall \& Smith, 2008). However, the research is lacking to see the effectiveness of such government policies influencing the tourism industry positively as well as negatively (Xie, 2003; Akama, 2002; Yang et al., 2008). Therefore, the understanding of the nexus between the role of government and tourism development is of crucial importance (Kubickova, 2019). 
Nonetheless, the involvement of the government is crucial for destination development and indispensable for contemporary economic activities (Glaeser \& Shleifer, 2002). World Travel and Tourism Council (2015) also stated that those economies showed higher performance in tourism have adopted a whole-of-government approach (government involvement). So the government intervention is needed for the development of the tourism industry while others believe the inability of governments to intervene may consequently lead to market failure (Michael, 2001; Hall, 2006; Stiglitz, 2012). The government can play a role to achieve the highest net impact with the legitimate authority for security and political stability in tourism development (Devine \& Devine, 2011; Kubickova \& Li, 2017; Bull, 1995; Tang \& Jang, 2009; Ritchie \& Crouch, 2003).

In addition, the tourism industry also faces the problem of free riders, as many industries are interrelated such as clean beaches will enhance the profitability of a hotel but also others will get a benefit, such as local restaurants and gift shops (Croes, 2011; Michael, 2001). Therefore, public goods are crucial to be considered as they can also influence the choice of tourists (Croes, 2011). In this perspective, the involvement of government is necessary for the maximization of destination competitiveness (Bull, 1995; Croes, 2011; Michael, 2001; Croes \& Kubickova, 2013). Nevertheless, the involvement of government and participation should be limited and controlled and should not compromise economic freedom, subsequently impacts incentives, productive efforts and effectiveness (De Haan \& Sturm, 2000). On one hand, economic freedom is very essential for the economy to grow and better function with improving tourism competitiveness so economic freedom paves the way for individuals to achieve business and entrepreneurial objectives (Berggren, 2003). As a flip side, the lack of freedom will create restrains and economic poverty, and diminish opportunities and jeopardize the required level of economic freedom (Sen, 1999; Stroup, 2007). Therefore, economic freedom is of high importance for the economy to grow, business to flourish, earn profits and enhance the level of economic activity and tourism competitiveness.

At the same time, some researchers have put the opposite view to support government involvement such as the non-interference of government will lead to an unbalanced growth of infrastructure, especially jeopardize the sustainability of environmental resources (Devine \& Devine, 2011). Consequently, some authors raised questions that up to what extent there should be the involvement of government for promoting tourism and also maintaining the level of economic freedom (Bartik, 1990; De Haan \& Sturm, 2000; Zerbe \& McCurdy, 1999).

In the literature, most studies focus on tourism competitiveness and its related indicators for the growth and development, such as the role of tourism in the development, role of human agency in the tourism competitiveness, tourism competitiveness and ethnolinguistic fractionalization, strategies for enhancing tourism competitiveness due to good and established hotels, inns, manpower, and restaurants (Cirstea, 2014; Kubickova et al., 2017; Das and Dirienzo, 2012; Tewal et al., 2017). However, the role of government in tourism industry and the institutional quality has been overlooked in the literature and there are a few studies discussing the relationship between the role of government and tourism competitiveness reflected by the environment of institutions in a country; such as the studies of Kubickova \& Li (2017), Kubickova (2016), and Kubickova (2019) discussed the same prevailing gap in the literature and identified some links and stressed for the exploration of such relationships. 
This study attempts to fulfill the said research gap by exploring the relationship between the role of government and tourism competitiveness in the selected developing countries of Asia Pacific: China, India, and Pakistan. The role and need for government involvement in the tourism industry are very important depending upon the stage of development of the tourism industry. The Tourism Area Life Cycle (TALC) model is quite helpful to understand the status of development in each destination and subsequently from higher to a lower level of government involvement is needed in the tourism industry.

A case-study research approach has been used for in-depth analysis and is employed for testing scientific theories and models in real-world situations. More precisely, the comparative case study has been utilized to see the difference in cases with an endeavour of understanding and examination (Croes, 2012; Yin, 2009; Veal, 2017; Smith, 2010).

This study will extend the methodology adopted by Kubickova and Li (2017) by introducing a new control variable relating to human resource development, measured by the Human Development Index (HDI) of the United Nations Development Program (UNDP, 1990). The HDI is important to consider due to their impact on tourism competitiveness as mentioned in the studies of Wright, McMahan, \& McWilliams, (1994); Poole \& Jenkins, (1996); Bulatovic, Durasevic, \& Stranjancevic, (2016). Furthermore, the practical implications suggested in this study will be helpful to adopt appropriate sound policies depending upon the current stage of development in each country and to enhance the tourism competitiveness along with the sustainability.

The structure of the paper is as follows. The second section deals with the theoretical foundation for tourism competitiveness, the role of government, economic freedom and tourism area life cycle model. The third section represents data and methodology along with empirical results. The fourth section gives a discussion of the obtained results. Finally, the last section ends with a conclusion, implications, and limitations.

\section{Theoretical Foundation}

\section{Tourism competitiveness and the role of government:}

The term competitiveness and sustainability are close to each other, however, the difference in exact meaning and scope varies. Competitiveness cannot be explained in a straightforward way. The use of the term competitiveness in the tourism sector covers different aspects such as the issue of using resources, effectiveness in the production and selling of goods and services, political and sustainable aspects as well as the involvement of the residents as an important stakeholder in a tourist destination.

In 2013, the definition given by OECD for the competitiveness of a tourist destination is considered comprehensive, as given as: "Tourism competitiveness for a destination is about the ability of the place to optimize its attractiveness for residents and non-residents, to deliver quality, innovative, and attractive (e.g. providing good value for money) tourism services to consumers and to gain market shares on the domestic and global market places, while ensuring that the available resources supporting tourism are used efficiently and in a sustainable way" (Dupeyras and MacCallum, 2013).

However, Buhalis (2000) referred to long-term profitability as an effort towards competitiveness while D'Hauteserre (2000) considers the maintenance and sustenance of 
market share as the competitiveness. The definition given by Dwyer and Kim (2003) looks appropriate due to the exhaustiveness as they stated, competitiveness produces job opportunities, increases real income under free-market conditions.

In this context, tourism competitiveness is regarded as the predecessor for destination development under free-market conditions. Therefore, a higher level of competitiveness leads to a higher level of economic growth and development. The economic growth and development could not be achieved without a considerable level of economic freedom as it helps the entrepreneurs to achieve their objectives (Sen, 1999). The imposition of restrictions decreases freedom which leads to a lack of economic and social freedom and consequently economic poverty and reduced level of tourism competitiveness (Pattanaik \& Xu, 1990; Croes, 2012; Sen, 1988; Sen, 1999). Hence, the level of freedom provided by the government impacts tourism competitiveness.

In the contemporary era, governments are more active and involve activities influencing to reap benefits from the tourism industry (Ritchie \& Crouch, 2003; Tang \& Jang, 2009). Governments implement different policies to influence the environmental, economic and social aspects because some researchers believe that governments have the legitimate power to implement policies for security, stability, and financial and legal framework to smooth the development of tourism by creating a conducive environment for competitiveness (Devine \& Devine, 2011). Such policies at the government level are more influential due to the strengthening of pull factors and improving the competitive position (Bull, 1995; Tang \& Jang, 2009).

The level of government intervention can vary from minimal level to the higher level, consequently influencing the level of freedom provided. In the literature, the role of government is controversial. In the economic history, some are the free-market enthusiasts, like Hayek and Friedman, others are in the favour of pragmatic approach that best suits in the situation at hand with government intervention, to the Marxism approach mainly propagated by Karl Marx and Lenin, believes in the no class system and stresses on the equality in society. Some believe that under certain situations, government intervention is necessary for implementing certain rules and activities (Wint, 1998; Acemoglu \& Verdier, 2000; Karnani, 2011). However, the question of government involvement is still debatable, like when and up to what extent there should be the involvement of government and which services governments should provide (Bartik, 1990; Wolf, 1997; Zerbe \& McCurdy, 1999; de Haan \& Strum, 2000).

The literature clearly identified that economic freedom is very important to achieve economic stability and efficiency in the labour and product markets which leads to competitiveness and balanced economies and also impacts the tourism industry (Das \& Dirienzo, 2010).

\section{Tourism area life cycle model and competitiveness:}

In 1980, R.W. Butler published his framework about the tourism area life cycle of evolution, illustrating a correlation between the number of tourists and time. Butler proposed that every destination evolves through six stages, characterised by specific characteristics, following the s-shape model. The six stages range from exploration, involvement, development, consolidation, stagnation and rejuvenation or decline (Figure 1). 


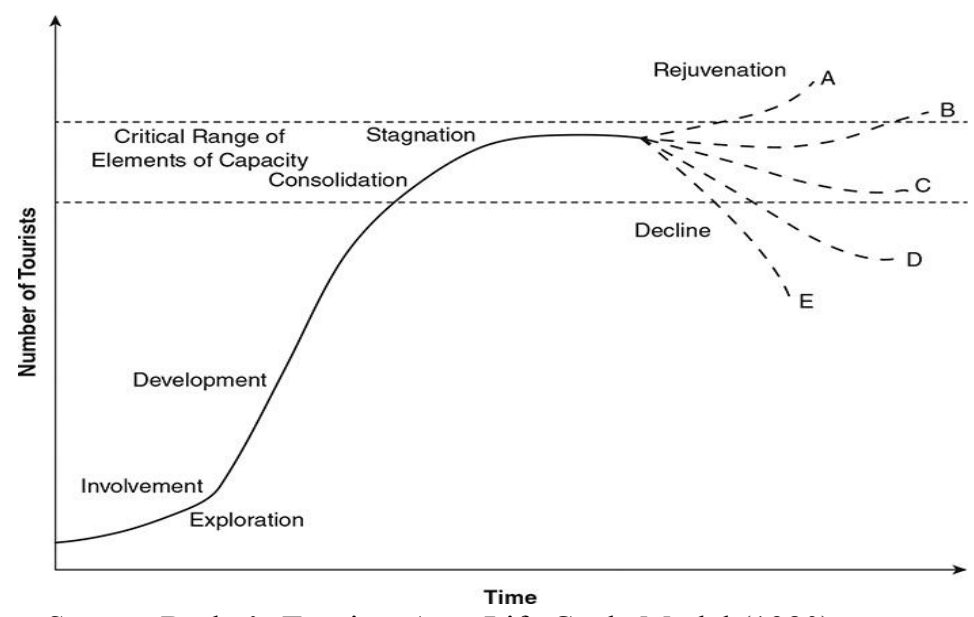

Source: Butler's Tourism Area Life Cycle Model (1980)

Figure 1: Tourism Area Life Cycle

Several studies attempted to model and explained the stage of destination development by considering the different types of variables from the exogenous and endogenous sides. Just by following the guidelines of Butler's, some used the number of arrivals to determine the level of destination development (Haywood, 1986; Moore \& Whitehall, 2005). In this vein, a study carried out by Yang, Ryan, \& Zhang (2014) also applied the Butler's Tourism Area Life Cycle Model (TALC) to analyse the role of government in policy-making and its implementation, they came up with the conclusion that the analytical framework of TALC is beneficial and useful even though China has command economy and the role of government is manifold in tourism development. On the parallel line, another study conducted by Petrevska \& CollinsKreiner (2017) assessed the validation and applicability of the TALC model for Macedonia and concluded that tourism in Macedonia is still in the development stage and needs a planned and well-established tourism process for improvement. Some authors included different determinants, like cultural diversity, availability of tourism facilities, geographical location and the law and order situation (ECLAC, 2010). These determinants are strongly linked with tourism competitiveness due to its resulting impact on the stage of evolution of tourist destinations (ECLAC, 2010).

This study focused to highlight the role of government due to its capability and ability to provide a framework for the development of the tourism industry (Zhong, Deng \& Xiang, 2008). Depending upon the stage of tourist destination, the role of government varies, if a destination is at an early stage the role of government will be higher in the form of giving incentives and encouraging the investors while later stages do not require much government involvement (ECLAC, 2010). Therefore, this study explored the relationship of tourism competitiveness, government and stage of development to put the required role of government in practice. 


\section{Research Methodology and Context}

\section{Data Collection:}

This study employed two constructs to achieve the objectives of observing the role of government in tourism, economic freedom, and tourism competitiveness. Apart from this, three control variables, corruption, economic development, and human resource have been used in order to capture the impact of extraneous variables. The annual time series data have been used for this study from 1995 to 2017 and has been obtained from different sources such as data for tourism receipt per capita from World Bank (WB), tourism added values as percentage of GDP from World Travel and Tourism Council (WTTC), average tourism receipt growth rate from World Tourism Organization (WTO), and United Nations Development Programme (UNDP).

The tourism competitiveness has different measures in the literature, such as a famous one is Travel and Tourism Competitiveness Index developed by World Economic Forum (WEF), however due to the non-contiguous availability on data and WEF started publication in 2007, therefore another index Tourism Competitiveness Index (TCI), developed by Croes (2011) have been utilised in this study. Furthermore, TCI used here shifts from inputs to outputs allowing for comparisons over time, specifically the outputs used are tourism receipt per capita, average tourism receipt growth rates, and tourism added values as a percentage of the GDP.

An index value has been estimated for each of the variables by using the following formula, as suggested by Croes (2011):

$$
X_{C i}=\frac{X_{C i}-X_{C \min i}}{X_{C \max i}-X_{C \min i}}
$$

Where c denotes the country and i represents the variables, along with their relevant maximum and minimum values and used to find the value of TCI.

The role of government in terms of intervention in the system has been used as a proxy by the level of freedom as measured by the Economic Freedom Index (EFI), developed and published by the Fraser Institute in Economic Freedom. This index considers the five major areas, such as the size of government, legal system and property rights, freedom to trade internationally, sound money, and regulations ranging from 0 (unfree) to 10 (fully free).

Finally, the Corruption Perception Index, introduced by Transparency International and taken up by the Heritage Foundation has been used as the first control variable, for Corruption. The countries with lower corruption indicate stability and government policies are in line for the development of tourism (Dirienzo, Das, Cort \& Burbridge, 2007; Das \& Dirienzo, 2010; Enright \& Newton, 2004). The countries with a higher level of development are considered more competitive with good law and order situation and infrastructure (Das \& Dirienzo, 2010). So, economic development measured by Gross Domestic Product (GDP) has been used as a second control variable and economic development strongly related to destination development. The third control variable, human resources measured by the Human Development Index (HDI). The countries with better human resources are more competitive and ultimately leads to more competitive tourist destinations (Wright, McMahan, \& McWilliams, 1994; Poole \& Jenkins, 1996; Bulatovic, Durasevic, \& Stranjancevic, 2016).

\section{Research Context:}


The study investigates the status of tourism competitiveness in the three important Asian countries, specifically China, India, and Pakistan and these countries are considered important due to their tourism potential for the future. The selected countries are geographically neighbouring countries and strategically important for tourism competitiveness. According to the International Monetary Fund (IMF, 2018), all three selected countries are developing countries however, China falls in the upper-middle countries. These countries have been selected due to the same geographical region (proximity to each other) and as an emerging tourist destination due to their cultural diversity, different levels of tourism competitiveness, the role of government and tourism development. Furthermore, all these countries are also putting efforts to improve the outlook of the tourism industry, yet limited studies are barely existing in these aforementioned countries and even in some cases non-existent. Therefore, the status of tourism in these countries will help to indicate their importance and relative competitiveness, government involvement in the system and stage of development of the TALC model.

Table 1: General Overview of Countries (2017)

\begin{tabular}{|l|c|c|c|}
\hline & China & India & Pakistan \\
\hline $\begin{array}{l}\text { International tourist } \\
\text { arrivals (in thousands) }\end{array}$ & 60740 & 15543 & 1750 \\
\hline $\begin{array}{l}\text { International tourist } \\
\text { receipts (US\$ Million) }\end{array}$ & 32617 & 27878 & 875 \\
\hline $\begin{array}{l}\text { Tourism contribution to } \\
\text { GDP (\%) }\end{array}$ & 11 & 9.4 & 7.4 \\
\hline $\begin{array}{l}\text { Tourism contribution to } \\
\text { employment (\%) }\end{array}$ & 10.3 & 117.51 & 6.5 \\
\hline $\begin{array}{l}\text { Quality of life index } \\
\text { (2018) }\end{array}$ & 97.92 & 21.9 & 36.3 \\
\hline $\begin{array}{l}\text { Poverty headcount ratio at } \\
\text { national poverty lines (\% } \\
\text { of population) (2011) }\end{array}$ & 12.7 & 8 & 104.63 \\
\hline
\end{tabular}

Source: World Bank (2017); Numbeo (2018); World Travel and Tourism Council (2018); Pakistan Tourism Development Corporation (2018).

China is an East Asian country and the most populous country in the world. The tourism industry in China is a significant industry. The splendid historic architecture, beautiful sceneries, and friendly people of China make it an attractive tourist destination for travellers and tourists. The reforms and openings of the 1970s contributed a lot for tourism and the tourism industry has expanded greatly. In this regard, the role of the Chinese government in easing the restrictions for movement and travelling is worthwhile to discuss and debate for assessment. In 2015, 56.9 million international tourists visited China and ranked fourth in the list of most visited countries (CEO World Magazine, 2016). Table 1 provides a brief overview of the selected countries. According to these statistics, China is receiving a good number of international arrival and subsequently somehow an impressive amount of international tourism receipts (World Bank, 2017). These statistics further reveal that 'Tourism contribution to GDP' and 'Tourism contribution to employment' is quite encouraging and almost equal to the world average (World Travel \& Tourism Council, 2018). Therefore, China is a very good case to see the status of tourism and competitiveness as compared to its neighbouring countries. 
The second country included for analysis is India which is a south Asian country and the second-most populous country of the world. The statistics of Table 1 reveal that the international tourist arrivals to India are more than 15 million with US\$ 27878 million international tourist receipts which indicates that the tourism industry in India is becoming stronger (World Bank, 2017). One interesting feature of Indian tourism is the medical tourism which is growing rapidly and its worth in 2015 was US\$ 3 billion and has the projections to be around US\$ 8 billion, by 2020 (The Economic Times, 2015). The 'Tourism contribution to GDP' and 'Tourism contribution to employment' is 9.4 percent and 8 percent respectively, pointing out that tourism industry in India is below the average world level and has potential to play role in the regional tourism in terms of competitiveness (World Travel \& Tourism Council, 2018).

From the perspective of Pakistan, a country of South Asia and the sixth-most populous country of the world has a lot of tourism potential due to its natural beauty, cultural heritage and impressive history. The British Backpacker Society has ranked Pakistan the world's top travel destination for 2018 while competing for 20 countries including Russia, India, China, and Kyrgyzstan, which explicated Pakistan as a paradise for tourists and one of the friendliest countries on earth, with beyond imagination mountain scenery (British Backpacker Society, 2017). According to the mentioned statistics and overview given in Table 1, Pakistan received 1.75 million international tourist arrivals with US\$ 875 million international tourist receipts which is far less than its potential (World Bank, 2017). The percentage values of 'Tourism contribution to GDP' and 'Tourism contribution to employment' are 7.4 and 6.5, respectively (World Travel \& Tourism Council, 2018). These values also show that Pakistan is probably at the initial stages of tourism development in the TALC model.

Therefore, this study will explore the relationships exist between the role of government (measured with economic freedom) and tourism competitiveness, that gets influence by the stage of the TALC model in the selected country. Hence, based on the findings, this study will offer some recommendations and solid policy implications for the growth and development of the tourism industry.

\section{Econometric Methodology:}

This study focuses to explore the relationships prevailing between the role of government and tourism competitiveness that gets impact based on the stage of development of the TALC model in which a particular country falls. Therefore, to analyse long-term relationships and causality, this study employed the Johanson cointegration test for analysing the long-run relationship, Granger causality test and Vector Error Correction Model (VECM) for short-run analysis by using the econometric software Eviews 10.0. Before testing, all the variables have been tested by the Augmented Dickey-Fuller (ADF) and Phillips-Perron (PP) test to see the status of stationarity.

Dickey and Fuller $(1979,1981)$ suggested a procedure to test for non-stationarity and which is equivalent to testing the presence of a unit-root. They also suggested an augmented version that incorporates additional lagged terms of the dependent variables for eliminating the autocorrelation. The generalized form of ADF used in this study by considering a constant in the random-walk process is as follows:

$$
\Delta Y t=a_{0}+v_{1} Y_{t-1}+\sum_{i=1}^{p} \beta_{i} \Delta Y_{t-1}+u_{t}
$$


The other test used is the Phillips-Perron test (1988), which is the generalization of the ADF test that will consider the less restrictive nature related to the error process.

In order to analyse the long-run relationship and restricted VAR (VECM), the variables should be cointegrated and in this study, the cointegration among variables has been tested by the Johansen approach. If the long-run relationship exists genuinely, then a linear combination of the variables, that is $I(0)$, that variables are cointegrated and the regression equation is no more spurious. It can be estimated by the following regression equation:

$$
T C I=\beta_{1}+\beta_{2} E F+\beta_{3} \text { Corruption }+\beta_{4} G D P+\beta_{5} H D I+u_{t}
$$

Taking the residuals,

$$
\hat{u}_{t}=T C I-\hat{\beta}_{1}+\hat{\beta}_{2} E F+\hat{\beta}_{3} \text { Corruption }+\hat{\beta}_{4} G D P+\hat{\beta}_{5} H D I
$$

If $\hat{u}_{t} \sim I(0)$, then TCI and EF, and other control variables are said to be cointegrated.

In order to test the long-term causality, the Granger causality test (1969), and Sims causality test $(1972,1980)$ can be used. However, the Granger causality test is more popular and this study has also used the same test for investing whether past values of a variable help to forecast the values of another variable (Song, Witt \& Li, 2008, Asteriou \& Hall, 2007). The VAR model can be used to see the causality and the general form will be as follows, however in case of more variables the model will be adjusted accordingly:

$$
y_{t}=a_{1}+\sum_{i=1}^{n} \beta_{i} x_{t-i}+\sum_{j=1}^{m} \gamma_{j} y_{t-j}+e_{1 t}
$$

Here the imposed restrictions are,

$$
\beta_{1}=\beta_{2}=\ldots=\beta_{n}=0
$$

If these restrictions are rejected, then $x_{t}$ Granger-causes $y_{t}$. In the case of more variables, as in this study, the block Granger causality test (block exogeneity test) has been used to see the causality among variables.

In order to see the short-term causality, the VECM is used because the variables are cointegrated, that is the case of restricted VAR. In this case, the error correction term is included in the VAR model which gives better insight by providing information on adjustment (Asteriou \& Hall, 2007; Binh, 2013).

\section{Data Analysis and Empirical Results}

\section{Unit-root test for stationarity:}

The results of the ADF and PP unit root test have been shown in Table 2 for all the variables including TCI, EF, Corruption, GDP, and HDI. All variables are non-stationary for China, India, and Pakistan and are stationary at the integration level of order one.

Table 2: ADF unit root test results

\begin{tabular}{llllll} 
Countries & Variables/Constructs & \multicolumn{2}{c}{ ADF test statistic } & Philips-Perron test statistic & Integration \\
\cline { 3 - 4 } & Level form & First Difference & Level form & First difference & level
\end{tabular}




\begin{tabular}{|c|c|c|c|c|c|c|}
\hline \multirow[t]{6}{*}{ China } & TCI & -4.3196 & $-8.0681 * * *$ & -4.3272 & $-10.4091 * * *$ & $\mathrm{I}(1)$ \\
\hline & Economic Freedom & -2.4555 & $-4.3541 * * *$ & -2.4414 & $-4.2622 * * *$ & $\mathrm{I}(1)$ \\
\hline & Corruption & -2.5433 & $-5.1170 * * *$ & -3.2575 & $-4.5965 * * *$ & $\mathrm{I}(1)$ \\
\hline & Gross Domestic & 1.0056 & $-4.8251 * * *$ & 2.1513 & $-5.0678 * * *$ & $\mathrm{I}(1)$ \\
\hline & Product & & & & & \\
\hline & $\begin{array}{l}\text { Human Development } \\
\text { Index }\end{array}$ & -1.5637 & $-5.5462 * * *$ & -1.2269 & $-5.5282 * * * *$ & $\mathrm{I}(1)$ \\
\hline \multirow[t]{5}{*}{ India } & TCI & -4.5864 & $-6.9077 * * *$ & -3.6876 & $-7.0858 * * *$ & $\mathrm{I}(1)$ \\
\hline & Economic Freedom & -2.2199 & $-5.6762 * * *$ & -2.6430 & $-5.8077 * * *$ & $\mathrm{I}(1)$ \\
\hline & Corruption & -0.2019 & $-5.1197 * * *$ & -0.1202 & $-5.1196 * * *$ & $\mathrm{I}(1)$ \\
\hline & $\begin{array}{l}\text { Gross Domestic } \\
\text { Product }\end{array}$ & 2.3851 & $-5.8504 * * *$ & 2.5837 & $-8.8473 * * *$ & $\mathrm{I}(1)$ \\
\hline & $\begin{array}{l}\text { Human Development } \\
\text { Index }\end{array}$ & 0.9207 & $-3.2657 * *$ & 0.8689 & $-3.2083 * *$ & $\mathrm{I}(1)$ \\
\hline \multirow[t]{5}{*}{ Pakistan } & TCI & -1.7641 & $-5.2412 * *$ & -1.6829 & $-5.4321 * * *$ & $\mathrm{I}(1)$ \\
\hline & Economic Freedom & -3.3406 & $-4.9888 * * *$ & -3.0435 & $-5.5935 * * *$ & $\mathrm{I}(1)$ \\
\hline & Corruption & -2.26 & $-6.8831 * * *$ & -2.1150 & $-8.7041 * * *$ & $\mathrm{I}(1)$ \\
\hline & $\begin{array}{l}\text { Gross Domestic } \\
\text { Product }\end{array}$ & 2.32 & $-3.4271 * *$ & 2.6707 & $-3.3967 * *$ & $\mathrm{I}(1)$ \\
\hline & $\begin{array}{l}\text { Human Development } \\
\text { Index }\end{array}$ & -0.5013 & $-8.9710 * * *$ & -8.9710 & $-8.8654 * * *$ & $\mathrm{I}(1)$ \\
\hline & level & & & & & \\
\hline & vel & & & & & \\
\hline & evel & & & & & \\
\hline
\end{tabular}

\section{Johansen Cointegration test:}

The Johansen Cointegration test requires that all the variables should be non-stationary and then all variables should be integrated of the same order. Further, the right choice of lag length is a very important vector autoregression model; therefore, for higher validity the right choice of lag length is necessary. Therefore, this study used the famous Akaike Information Criterion (AIC) and Schwarz Information Criterion (SIC) for the right choice of lag length. The results indicated that the optimum lag length is one for the Johansen cointegration test.

Table 3 shows the results of the Johansen cointegration test with the values of trace statistic and corresponding critical values at the 5 percent level of significance. The null hypotheses represent the number of cointegration vectors and if the trace statistic is greater than the corresponding critical values, then the null hypothesis will be rejected. The results indicate that there are five, two and two cointegrating relationships that prevail among the chosen variables in China, India, and Pakistan, respectively.

Table 3: Cointegration tests-Johansen approach:

\begin{tabular}{llccc} 
& & Trace statistic & $\begin{array}{c}\text { Critical Value } \\
\mathbf{( 5 \% )}\end{array}$ & Probability \\
\hline China (TCI, EF, Corruption, GDP, HDI) & Ho: $\mathrm{r}=0^{*}$ & 113.14 & 69.8189 & 0.0000 \\
& Ho: $\mathrm{r} \leq 1^{*}$ & 67.5399 & 47.8561 & 0.0003 \\
& Ho: $\mathrm{r} \leq 2^{*}$ & 36.5908 & 29.7970 & 0.0071 \\
& Ho: $\mathrm{r} \leq 3^{*}$ & 19.5623 & 15.4947 & 0.0115 \\
India (TCI, EF, Corruption, GDP, HDI) & Ho: $\mathrm{r} \leq 4^{*}$ & 7.3265 & 3.8415 & 0.0068 \\
& Ho: $\mathrm{r}=0^{*}$ & 91.9591 & 69.8189 & 0.0003 \\
& Ho: $\mathrm{r} \leq 1^{*}$ & 48.3701 & 47.8561 & 0.0447 \\
& Ho: $\mathrm{r} \leq 2$ & 19.9934 & 29.7971 & 0.4233 \\
Pakistan (TCI, EF, Corruption, GDP, HDI) & Ho: $\mathrm{r} \leq 3$ & 9.3699 & 15.4947 & 0.3323 \\
& Ho: $\mathrm{r}=0^{*}$ & 136.77 & 69.82 & 0.0000 \\
& Ho: $\mathrm{r} \leq 1^{*}$ & 69.5316 & 47.8561 & 0.0001 \\
& Ho: $\mathrm{r} \leq 2$ & 25.0667 & 29.7971 & 0.1591 \\
& Ho: $\mathrm{r} \leq 3$ & 9.0010 & 15.49471 & 0.3653
\end{tabular}


Trace test indicates 2 cointegrating eqn(s) at the 0.05 level

* denotes rejection of the hypothesis at the 0.05 level

** MacKinnon-Haug-Michelis (1999) p-values

Source: Author's computations from Eviews

\section{Block Granger Causality test:}

The block granger causality test, as discussed in the methodology section examines the causality that how a lagged variable Granger causes the other variable included in the analysis and block granger causality test is carried out for more than two variables (Song, Witt \& Li, 2008).

Table 4 shows a long-run causality of the variables of interest, economic freedom, and tourism competitiveness and other control variables included in this study. The results reveal that economic freedom causes tourism competitiveness in the case of China. However, such a relationship is not prevailing significantly for India and Pakistan. Apart from that, Corruption and GDP cause significantly tourism competitiveness in the case of China and Pakistan and this is according to expectations. In Pakistan, Corruption also causes significantly to Economic Freedom and vice versa. Further, Human Development impacts GDP in Pakistan and a Higher level of Tourism Competitiveness also improves Human Development. Economic Freedom provided by the government also helps to boost the level of Human Development in China.

Table 4: VEC Granger Causality

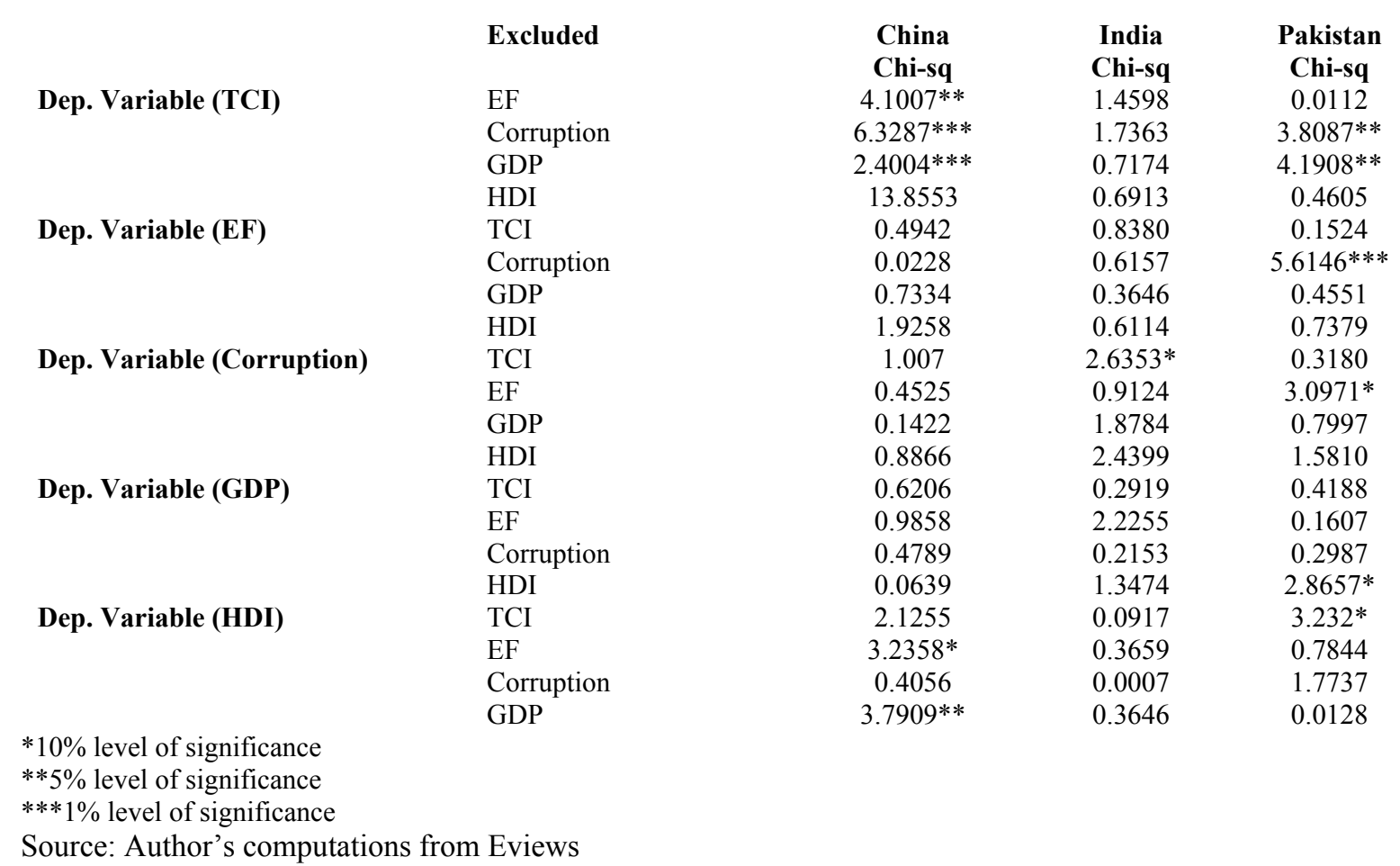

\section{Vector Error Correction Model - Short-term analysis:}

The VECM results reveal short-term causality between tourism competitiveness and economic freedom for the selected three countries (China, India, and, Pakistan), as represented in Table 5. The results indicate that there is no evidence of short-term causality in India and Pakistan, however, a unidirectional short-term causality exists in the case of China where economic freedom negatively impacts tourism competitiveness with the coefficient value is being equal to -0.0434 . 
Along with the VEC model, some diagnostic tests have also been executed, precisely are the Portmanteau Autocorrelation Test and the White Homoskedasticity Test. The results of these tests have also been presented in Table 5. The Portmanteau test for autocorrelation, tests the null hypothesis about the existence of no serial correlation through the Q-Statistic and the adjusted Q-Statistic, for all the three countries. Similarly, through the White Homoskedasticity test, the null hypothesis of no-heteroskedasticity has been tested. The values in the table show that there is no issue of serial correlation and heteroscedasticity with the data. So, the model passed all the tests in the case of China, India, and Pakistan. 
Table 5: VEC Results and Diagnostic Tests

\begin{tabular}{|c|c|c|c|c|c|c|}
\hline & \multicolumn{2}{|l|}{ China } & \multicolumn{2}{|l|}{ India } & \multicolumn{2}{|l|}{ Pakistan } \\
\hline & $\mathrm{D}(\mathrm{TCI})$ & $\mathrm{D}(\mathrm{EF})$ & $\mathrm{D}(\mathrm{TCI})$ & $\mathrm{D}(\mathrm{EF})$ & $\mathrm{D}(\mathrm{TCI})$ & $\mathrm{D}(\mathrm{EF})$ \\
\hline CointEq1 & $-1.5629[-3.9189]$ & $8.4647[1.2696]$ & $-0.0758[-0.4162]$ & $-2.6626[-1.4985]$ & $0.08795[1.1899]$ & $2.3296[2.5157]$ \\
\hline$D(T C I(-1))$ & $0.1624[0.6669]$ & $-2.8607[-0.7030]$ & $0.0182[0.0620]$ & $-0.8272[-0.2895]$ & $-0.2203[-0.9935]$ & $-1.0844[-0.3904]$ \\
\hline$D(E F(-1))$ & $-0.04344 * *[-2.0250]$ & $0.0317[0.08851]$ & $0.0343[1.2082]$ & $-0.2657[-0.9583]$ & $0.0022[0.1057]$ & $-0.1631[-0.6394]$ \\
\hline$D($ Corruption $(-1))$ & $0.3629[2.5156]$ & $0.3646[0.1512]$ & 0.2924 [1.3177] & $-1.6994[-0.7847]$ & $-0.1740[-1.9516]$ & $-2.6466[-2.3695]$ \\
\hline$D(G D P(-1))$ & 9.57E-05 [1.5493] & $-0.0009[-0.8564]$ & $0.0004[0.8469]$ & $-0.0030[-0.6039]$ & $-0.0067[-2.0472]$ & $0.0277[0.6746]$ \\
\hline$D(H D I(-1))$ & 61.1550 [3.7223] & $-381.1508[-1.3877]$ & $-24.5423[-0.8314]$ & 225.2662 [0.7819] & $7.0487[0.6786]$ & $-111.7843[-0.8590]$ \\
\hline$C$ & $-0.6511[-3.5742]$ & $4.3564[1.4306]$ & $0.1426[0.6102]$ & $-1.1200[-0.4911]$ & $0.0457[0.5414]$ & $0.2470[0.2334]$ \\
\hline$R$-square & 0.6892 & 0.3232 & 0.2349 & 0.3308 & 0.4761 & 0.3904 \\
\hline F-statistic & 5.1751 & 1.1141 & 0.7166 & 1.1532 & 2.1205 & 1.4943 \\
\hline Akaike Information Criterion (AIC) & -1.4268 & 4.2061 & -0.5426 & 4.0141 & -0.8903 & 4.1657 \\
\hline Schwarz Information Criterion (SIC) & -1.0786 & 4.5543 & -0.1944 & 4.3623 & -0.5421 & 4.5138 \\
\hline Joint AIC & 6.9635 & & 4.4611 & & 0.6506 & \\
\hline Joint SIC & 8.9531 & & 6.4506 & & 2.6402 & \\
\hline Diagnostic tests & & & & & & \\
\hline White Heteroskedasticity Test & $184.4630(0.7677)$ & & $184.1402(0.4007)$ & & $178.5371(0.5168)$ & \\
\hline Portmanteau Autocorrelation Test & $\begin{array}{l}\text { Q-Stat }=37.8095(0.7677) \\
\text { Adj. Q-Stat }=40.9608 \\
(0.6437)\end{array}$ & & $\begin{array}{l}\text { Q-Stat }=25.6185(0.9911) \\
\text { Adj. Q-Stat }=27.9423 \\
(0.9784)\end{array}$ & & $\begin{array}{l}\text { Q-Stat }=45.8789 \\
\text { Adj. Q-Stat }= \\
49.9978(0.2816)\end{array}$ & \\
\hline $\begin{array}{l}\text { Note: The values in brackets and pa } \\
* 10 \% \text { level of significance } \\
* * 5 \% \text { level of significance } \\
* * * 1 \% \text { level of significance } \\
\text { Source: Author's computations from }\end{array}$ & ntheses are t-statistics ar & robabilities, respe & $\mathrm{D}$, indicates the first di & rence. & & \\
\hline
\end{tabular}




\section{Discussion}

The results of this study are very interesting in terms of the relationship between tourism competitiveness and the economic freedom provided by the government (the role of government) depending upon the stage of the tourism area life-cycle model. The obtained results are somehow complicated and complex and need careful interpretation for the right understanding.

The Tourism Competitiveness Index (TCI), composed of three outputs, tourism receipts per capita, average tourism receipt growth rates and tourism added values as a percentage of the GDP, following the index developed by Croes (2011). The graphic representation of this TCI indicates that tourism competitiveness in three countries are of mixed nature as these countries experienced ups and downs over the studied period of time (Figure 2). However, tourism competitiveness in China was relatively stable but competitiveness is falling from the previous two years and increasing in the case of India and Pakistan which is quite good and encouraging to reap the potential benefits of tourism. Figure 2 indicates that overall China is having a higher level of the TALC model. Among the three countries, Pakistan was having the highest competitiveness in 2011 with a competitiveness score of 0.85 .

The level of government involvement measured in terms of economic freedom was different in three countries during the initial years of analysis included in this study, from 1995 to 2005 while after that the provided economic freedom in India and Pakistan is almost the same and lesser in China (Figure 3). However, during the previous few years, economic freedom in China has started to rise while the fall in India and Pakistan considerably.

In terms of corruption level, initially, China was having a higher level of corruption but from the previous few years, the level of corruption in China and India is the same. However, the level of corruption is lesser in Pakistan as compared to China and India (Figure 4).

When it comes to GDP, China is having a higher level of GDP than India while Pakistan is having the lowest level and this is depending upon the sizes of their economies. Although the level of development and GDP affects tourism competitiveness in the respective country yet the direct comparison of GDP with other countries is not reasonable due to the different sizes of their economies. (Figure 5).

The consideration of Human Development Index (HDI) is important due to its impact on the competitiveness as studies show that better human resources lead to higher levels of tourism competitiveness (Wright, McMahan, \& McWilliams, 1994; Poole \& Jenkins, 1996; Bulatovic, Durasevic, \& Stranjancevic, 2016). Figure 6 confirms that China with better HDI has a higher level of tourism competitiveness. 


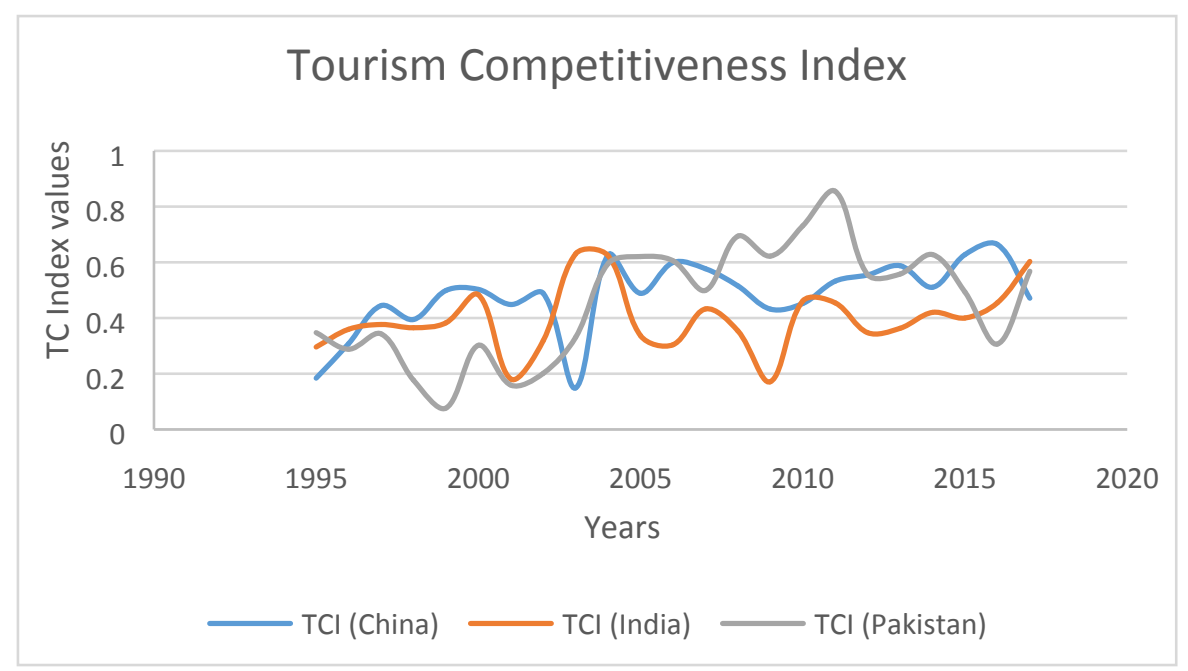

Figure 2: Tourism Competitiveness Index for China, India, and Pakistan

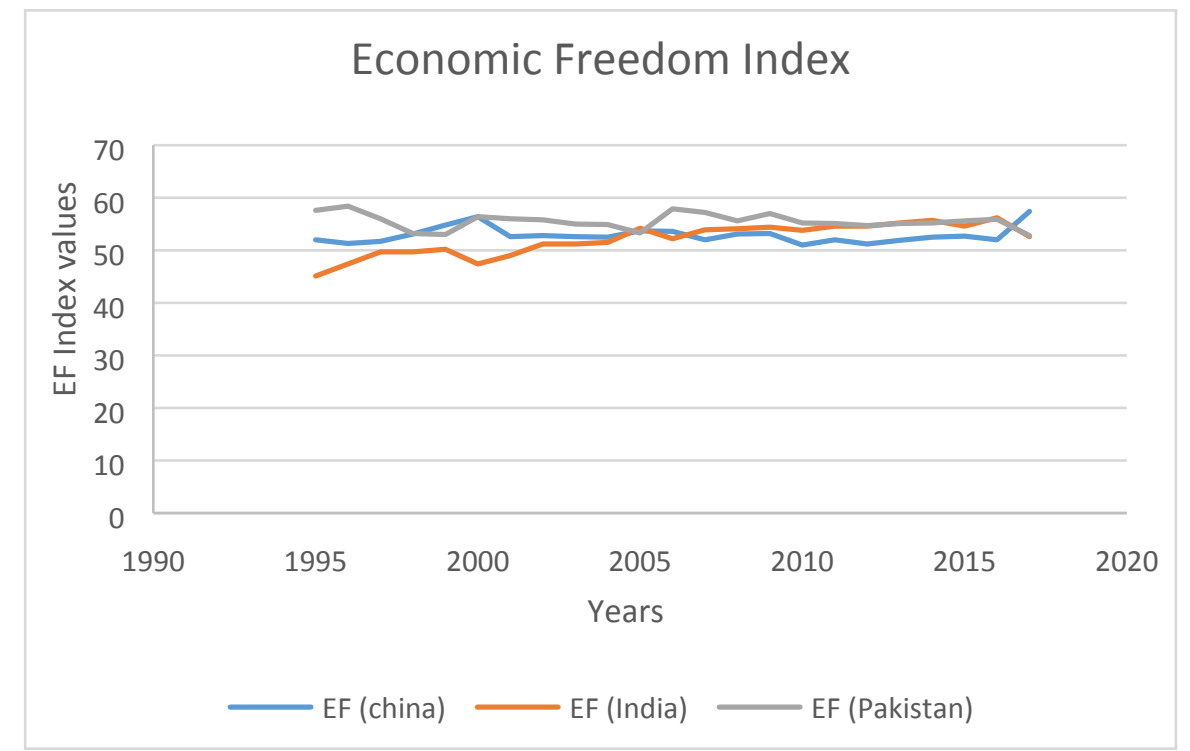

Figure 3: Economic Freedom Index for China, India, and Pakistan

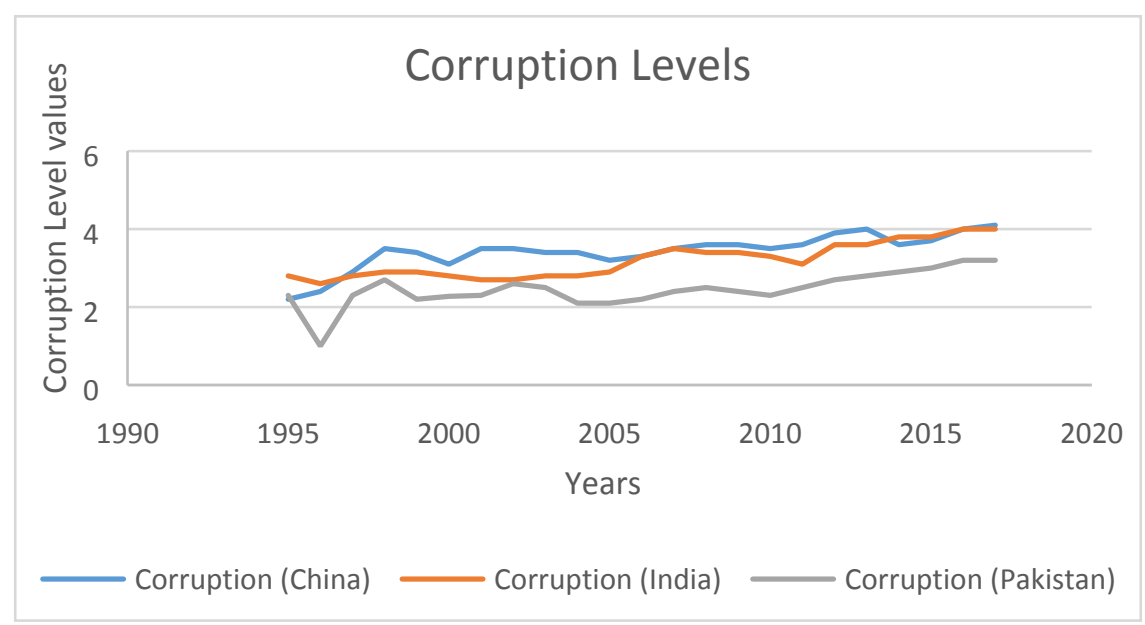

Figure 4: Corruption Levels for China, India, and Pakistan 


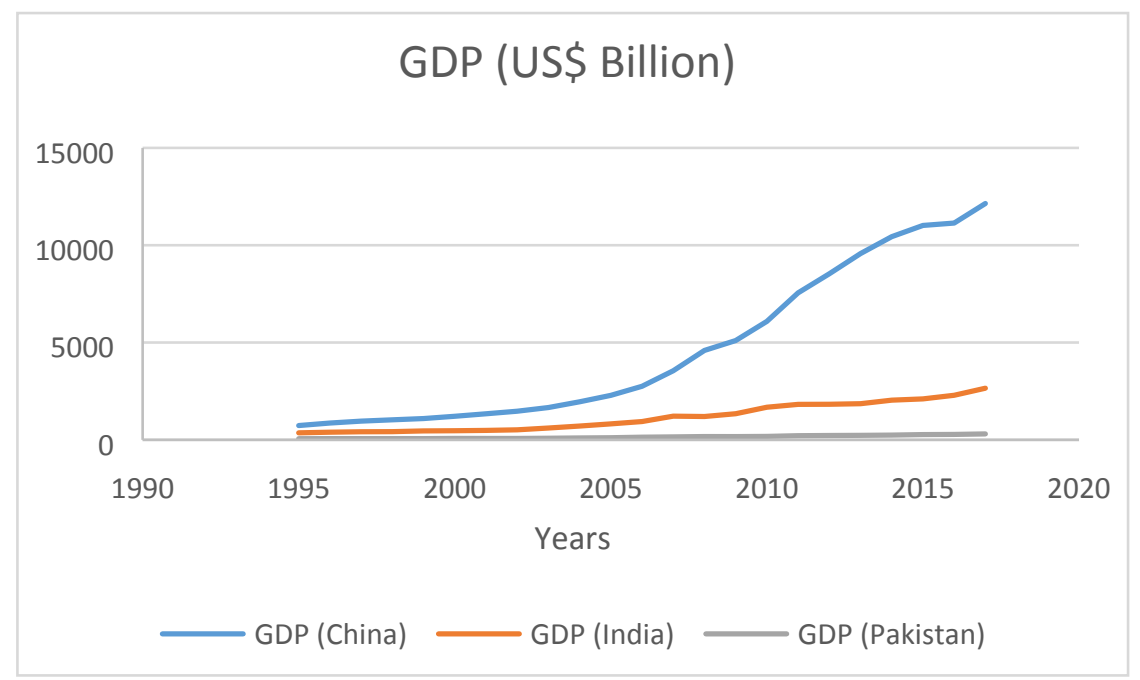

Figure 5: GDP for China, India, and Pakistan

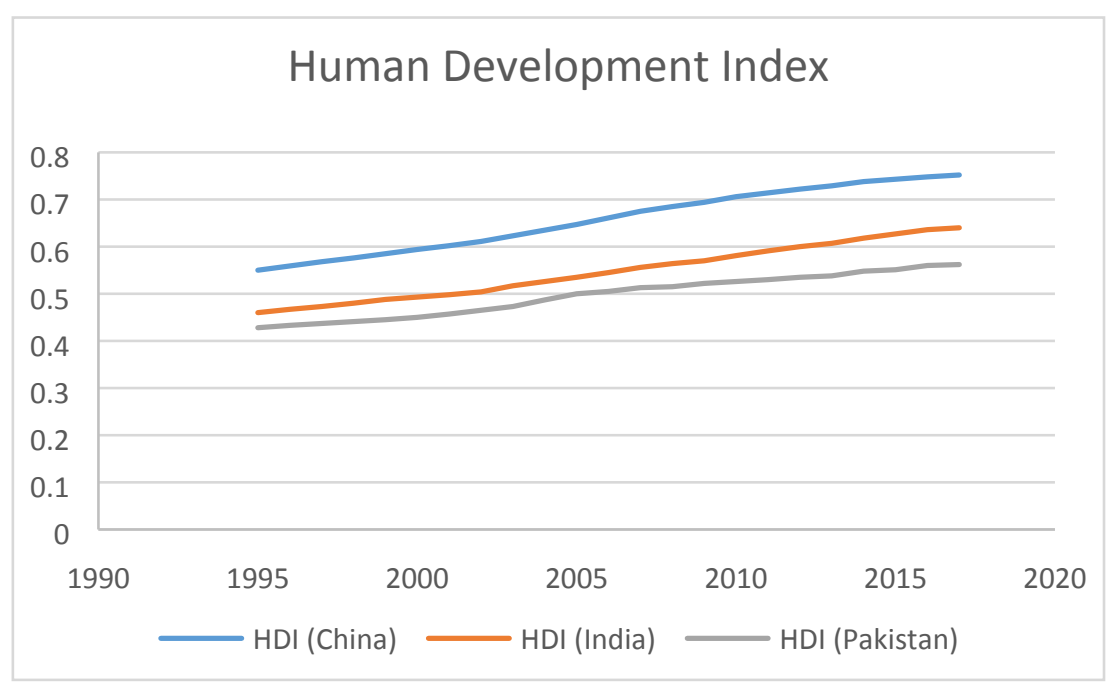

Figure 6: Human Development Index for China, India, and Pakistan

China:

In the case of China, the results of this study indicate that there is a long-run causality between economic freedom and tourism competitiveness (Table 4 \& Table 5). In other words, the level of economic freedom provided by the government impacts significantly the level of tourism competitiveness. Historically, it can be envisaged back to a few decades from the government focus on less intervention, reforms and be opened for tourism. Therefore, over the years China emerged as Asia's giant be receiving 57 million tourists and these are around 20 percent of international arrivals in Asia (World Economic Forum, 2017).

The current position of China puts it in the stage of development but close to the consolidation stage depending upon its current policies. However, the current decline in tourism competitiveness in China should be considered cautiously (Figure 2). The government and other relevant authorities should consider the fact of increasing competencies in the neighbouring countries and come forward with a plan to sustain tourism growth. 
India:

In the context of India, the results reveal that there is no relationship between tourism competitiveness and economic freedom (Table $4 \&$ Table 5). This is due to the fact that from previous many years the level of economic freedom is almost the same, however, the increasing level of tourism competitiveness is quite encouraging to get a higher share in tourism (Figure 2). This increased level of competitiveness is definitely due to the higher influence of other factors. However, this notion also supports Friedman and Hayek's view of less government intervention as more government involvement will lead to jeopardizing the necessarily needed freedom (Stroup, 2007). From the previous few years, the increasing level of competitiveness in India can also be verified by the current Travel and Tourism Competitiveness Report by World Economic Forum (Calderwood \& Soshkin, 2019), mentioning that India moved up six places in the competitiveness index and this is quite impressive.

The lack of relationship between tourism competitiveness and economic freedom is surprising in this case which is quite important in developing countries. While the importance of economic freedom and the role of government involvement could not be denied due to its potential to contribute considerably to reaping tourism benefits.

According to the current status of India, it can be deduced that tourism in India is somewhere in between the Involvement and Development stage. The role of government can be helpful to boost tourism further and enhance its status but this involvement must be controlled otherwise it may impact negatively if the government oversteps its boundaries.

Pakistan:

In terms of Pakistan, this study is not revealing any short-term and long-term association between tourism competitiveness and economic freedom, as can be verified from Table 4 and Table 5. The obvious reason is over the years the static role of government in providing economic freedom (Figure 3). However, Figure 3 also indicates that from the previous two years the level of economic freedom is less but the resulting increase in tourism competitiveness is amazing. Contemporary to this time; the happening of other events, the intention of government and related policies cannot be ignored for a better understating of the situation. Before 2014, Pakistan was facing bad law and order situation, especially poor security situation in tribal areas, hiking enticing destinations and areas rich in natural beauty. Furthermore, the increased involvement of the government to attract tourists by introducing different policies and tour packages can be observed with the resulting enhanced level of tourism competitiveness (Figure $2 \& 3$ ).

The state of affairs refers to that country is at Exploration and Involvement stage and as a destination, Pakistan has a lot of potentials to emerge for getting higher status and attracting more and more tourists. The active involvement of government in tourism planning and destination development in very important to achieve these goals in the coming years.

\section{Conclusion and Implication}

The study investigated the tourism competitiveness, its relationship with economic freedom to analyse the role of government involvement and the stage of tourism development, developed by Butler in the Tourism Area Life Cycle (TALC). In the whole scenario of tourism development, the role of government is very important to expedite the process of tourism 
development and this role changes according to the stage of development. The involvement of government can put bi-directional impacts; therefore, the interference of government should be controlled and careful because the higher level of government involvement can even reduce the tourism competitiveness (Michael, 2001; Stiglitz, 2012; Devine and Devine, 2011; Berggren, 2003). The results lead us to the conclusion according to the respective status of each country; China needs less involvement of government while India and Pakistan need a higher level of government involvement with long term policy planning. This is quite in line with the suggestions given previously that government policies are more important in the stage of 'Exploration', 'Involvement' of TALC Model to give incentives and develop infrastructure, and somehow at the stage of 'Development' where government involvement is crucial for sustainability and maximum gains (ECLAC, 2010).

However, along with the understanding of the relationship between tourism competitiveness and economic freedom, it is also necessary to know that a higher level of economic freedom does not necessarily improve competitiveness and a lower level of economic freedom does not necessarily reduce competitiveness. This argument can be regarded that there is an 'optimal' level of economic freedom to move from one stage of development to the next stage of development. The same can be verified in this study, as in recent years, China even reduced the level of tourism competitiveness despite increasing the level of economic freedom (See Figure $2 \&$ Figure 3). On the other hand, it can be observed the higher level of tourism competitiveness as a result of reducing economic freedom (See Figure $2 \&$ Figure 3 ). The logic behind is the consideration of the stage of development with respect to TALC model, as during the initial stages of tourism development, more intervention and involvement of government is a need as compared to the later stages, therefore, the benchmark is that there should be right level of government involvement for the tourism development. Furthermore, as mentioned earlier there is also a relationship between economic freedom and economic growth (Bull, 1995; Croes, 2011; Michael, 2001). So, a higher level of economic freedom resulting in a higher level of economic growth and can be seen in the case of China as compared to India, and Pakistan (See Figure 3 \& Figure 5).

This study has come up with a few important managerial implications. One clear suggestion is that governments should clearly understand their current status and the level of competitiveness and then formulate their policies accordingly. For example, the understanding of competitiveness and the current stage of development will help to act correspondingly to become more competitive and move to the next stage of tourism development. Like the current stage of tourism development, India and Pakistan require more government involvement and solid long-term policies to accelerate the journey towards the higher level of tourism competitiveness. Therefore, the governments can either increase or decrease the level of economic freedom according to the prevailing state of affairs which will positively impact tourism competitiveness.

The results of this study are specific to the three selected countries (China, India, and Pakistan) and cannot be generalized, however, if some country finds in the same situations then results can be generalized somehow but with caution. In addition, such studies can be applied to other countries more extensively to understand the relationships better and finding the position of the respective country on the stage of development in terms of the TALC model. This study also included a new important variable, 'Human Development Index' to capture the impact of 
the development of human resources in the system as suggested by Kubickova and Li (2017) for future research work.

No research is without limitations, and this research also has some limitations which might be considered for future work. On important limitation is the inclusion of the control variable corruption. In order to incorporate the impact of corruption, the corruption perception index developed by Transparency International (TI) in 1995 has been used. However, TI changed of methodology and converted the transparency index from 0 to 100 instead of 0 to 10 . Therefore, for the sake of comparison and to maintain the prevalence, this study used the Corruption Perception Index (CPI) by again converting the scale from 0 to 100 to 0 to 10 , to maintain symmetry. Therefore, this approximation might not be so strong and can be regarded as a limitation of this study. Apart from that, the use of the Johansen Cointegration test on a small sample size is a poor approximation (Johansen, 2002). Keeping this weakness in mind, the larger sample size is suggested for future studies to reach a higher level of accuracy.

\section{ACKNOWLEDGMENT}

The authors are grateful for the financial assistance provided by the Internal Grant Agency of FaME, TBU No. IGA/FaME/2020/005, titled, "The sustainability practices in the eco and rural tourism". 
References:

Acemoglu, D., \& Verdier, T. (2000). The choice between market failures and corruption. American economic review, 90(1), 194-211.

Akama, J. S. (2002). The role of government in the development of tourism in Kenya. International Journal of Tourism Research, 4(1), 1-14.

Andereck, K. L., Valentine, K. M., Vogt, C. A., \& Knopf, R. C. (2007). A cross-cultural analysis of tourism and quality of life perceptions. Journal of Sustainable Tourism, 15(5), 483-502.

Asteriou, D., \& Hall, S. G. (2007). Applied Econometrics: a modern approach, revised edition. Hampshire: Palgrave Macmillan.

Bartik, T. J. (1990). The market failure approach to regional economic development policy. Economic Development Quarterly, 4(4), 361-370.

Berggren, N. (2003). The benefits of economic freedom: a survey. The independent review, 8(2), 193-211.

Binh, P. (2013). Unit Root Tests, Cointegration, ECM, VECM, and Causality Models. Topics in Time Series Econometrics, Article, 110.

British Backpacker Society (2017). Available at:

https:/gulfnews.com/news/asia/pakistan/pakistan-tops-list-of-world-s-best-travel-destinationfor-2018-1.2148655 [Online]. Retrieved on: 25 August, 2019.

Buhalis, D. (2000). Marketing the competitive destination of the future. Tourism management, 21(1), 97-116.

Bulatović, I., Đurašević, S., \& Stranjančević, A. (2016). Human resources as a factor of competitiveness and quality in the hospitality industry. In SITCON-Singidunum International Tourism Conference, Belgrade, Serbia, 30th September. Available online: https://singipedia. singidunum. ac. rs/preuzmi/42427-human-resourcesas-a-factor-of-competitiveness-andquality-in-the-hospitality-industry/2625.

Bull, A. (1995). Economics of travel and tourism (No. Ed. 2). Longman Australia Pty Ltd.

Butler, R. W. (1980). The concept of a tourist area cycle of evolution: implications for management of resources. Canadian Geographer/Le Géographe canadien, 24(1), 5-12.

Calderwood, L., \& Soshkin, M. (2019). The Travel \& Tourism Competitiveness Report 2019. In World Economic Forum. http://www3. weforum. org/docs/WEF_TTCR_2019. pdf.

CEO World Magazine (2016). Available at: https://ceoworld.biz/2016/04/26/worlds-top-10visited-countries-international-tourists-2015/ [Online]. Retrieved on: 14 August, 2019.

Cîrstea, Ş. D. (2014). Travel \&Tourism Competitiveness: A Study of World's Top Economic Competitive Countries. Procedia Economics and Finance, 15, 1273-1280.

Croes, R. (2011). Measuring and explaining competitiveness in the context of small island destinations. Journal of travel research, 50(4), 431-442. 
Croes, R. (2012). Assessing tourism development from Sen's capability approach. Journal of Travel Research, 51(5), 542-554.

Croes, R., \& Kubickova, M. (2013). From potential to ability to compete: Towards a performance-based tourism competitiveness index. Journal of Destination Marketing \& Management, 2(3), 146-154.

Das, J., \& Dirienzo, C. (2010). Tourism competitiveness and corruption: A cross-country analysis. Tourism economics, 16(3), 477-492.

Das, J., \& Dirienzo, C. E. (2012). Tourism competitiveness and the role of fractionalization. International Journal of Tourism Research, 14(3), 285-297.

De Haan, J., \& Sturm, J. E. (2000). On the relationship between economic freedom and economic growth. European Journal of Political Economy, 16(2), 215-241.

Devine, A., \& Devine, F. (2011). Planning and developing tourism within a public sector quagmire: Lessons from and for small countries. Tourism Management, 32(6), 1253-1261.

d'Hauteserre, A. M. (2000). Lessons in managed destination competitiveness: the case of Foxwoods Casino Resort. Tourism Management, 21(1), 23-32.

Dickey, D. A., \& Fuller, W. A. (1979). Distribution of the estimators for autoregressive time series with a unit root. Journal of the American statistical association, 74(366a), 427-431.

Dickey, D. A., \& Fuller, W. A. (1981). Likelihood ratio statistics for autoregressive time series with a unit root. Econometrica: journal of the Econometric Society, 1057-1072.

DiRienzo, C. E., Das, J., Cort, K. T., \& Burbridge, J. (2007). Corruption and the role of information. Journal of International Business Studies, 38(2), 320-332.

Dredge, D., \& Jamal, T. (2015). Progress in tourism planning and policy: A post-structural perspective on knowledge production. Tourism Management, 51, 285-297.

Dredge, D., \& Jenkins, J. M. (2007). Tourism planning and policy. Milton: John Wiley.

Dupeyras, A., \& MacCallum, N. (2013). Indicators for measuring competitiveness in tourism: a guidance document, OECD Tourism Papers, 2013/02, OECD Publishing.

Dwyer, L., \& Kim, C. (2003). Destination competitiveness: determinants and indicators. Current issues in tourism, 6(5), 369-414.

ECLAC (2010). The tourism sector and the global economic crisis: development implications for the Caribbean. Economic commission for Latin America and the Caribbean. Available at: https://www.cepal.org/en/publications/38650-tourism-sector-and-global-economic-crisisdevelopment-implications-caribbean [Online]. Retrieved on: 14 August, 2019.

Enright, M. J., \& Newton, J. (2004). Tourism destination competitiveness: a quantitative approach. Tourism management, 25(6), 777-788.

Glaeser, E. L., \& Shleifer, A. (2002). Legal origins. The Quarterly Journal of Economics, 117(4), 1193-1229. 
Granger, C. W. J. (1969). Investigating Causal Relationships by Econometric Models and Cross-Spectral Methods', Econometrica, 37, 424-438.

Hall, C. M. (2011). A typology of governance and its implications for tourism policy analysis. Journal of Sustainable Tourism, 19(4-5), 437-457.

Hall, J. C. (2006). Positive externalities and government involvement in education. Journal of Private Enterprise, 21(2).

Haywood, K. M. (1986). Can the tourist-area life cycle be made operational?. Tourism management, 7(3), 154-167.

International Monetary Fund (2018). World economic outlook, database - WEO groups and aggregates information. Available at:

https://www.imf.org/external/pubs/ft/weo/2018/02/weodata/groups.htm [Online]. Retrieved on: 11 November, 2019.

Johansen, S. (2002). A small sample correction for the test of cointegrating rank in the vector autoregressive model. Econometrica, 70(5), 1929-1961.

Karnani, A. (2011). "Doing well by doing good": The grand illusion. California Management Review, 53(2), 69-86.

Kubickova, M. (2016). The Role of Government in Tourism: Linking Competitiveness, Freedom, and Developing Economies. Czech Journal of Tourism, 5(2), 73-92.

Kubickova, M. (2019). The impact of government policies on destination competitiveness in developing economies. Current Issues in Tourism, 22(6), 619-642.

Kubickova, M., \& Li, H. (2017). Tourism competitiveness, government and tourism area life cycle (TALC) model: the evaluation of Costa Rica, Guatemala and Honduras. International Journal of Tourism Research, 19(2), 223-234.

Kubickova, M., Croes, R., \& Rivera, M. (2017). Human agency shaping tourism competitiveness and quality of life in developing economies. Tourism management perspectives, 22, 120-131.

Michael, E. (2001). Public choice and tourism analysis. Current Issues in Tourism, 4(2-4), 308-330.

Moore, W., \& Whitehall, P. (2005). The tourism area lifecycle and regime switching models. Annals of Tourism Research, 32(1), 112-126.

Numbeo (2018). Quality of Life Index for country 2018. Available at: https://www.numbeo.com/quality-of-life/rankings_by_country.jsp?title=2018 [Online]. Retrieved on: 14 September, 2019.

Pakistan Tourism Development Corporation (2018). Available at: https://www.dawn.com/news/1403800 [Online]. Retrieved on: 14 August, 2019.

Petrevska, B., \& Collins-Kreiner, N. (2017). A double life cycle: determining tourism development in Macedonia. Journal of Tourism and Cultural Change, 15(4), 319-338. 
Phillips, P. C., \& Perron, P. (1988). Testing for a unit root in time series regression. Biometrika, 75(2), 335-346.

Poole, M., \& Jenkins, G. (1996). Competitiveness and human resource management policies. Journal of General Management, 22(2), 1-19.

Ritchie, J. B., \& Crouch, G. I. (2003). The competitive destination: A sustainable tourism perspective. Cabi.

Sambharya, R. B., \& Rasheed, A. A. (2015). Does economic freedom in host countries lead to increased foreign direct investment?. Competitiveness Review, 25(1), 2-24.

Sen, A. (1988). Freedom of choice: concept and content. European Economic Review, 32(23), 269-294.

Sen, A. (1999). Development as freedom Anchor Books. New York.

Sims, C. A. (1972). Money, income, and causality. The American economic review, 62(4), 540-552.

Sims, C. A. (1980). Macroeconomics and reality. Econometrica: journal of the Econometric Society, 48, 1-48.

Smit, A. J. (2010). The competitive advantage of nations: is Porter's Diamond Framework a new theory that explains the international competitiveness of countries?. Southern African Business Review, 14(1).

Song, H., Witt, S. F., \& Li, G. (2008). The advanced econometrics of tourism demand. Routledge.

Stiglitz, J. E. (2012). The price of inequality: How today's divided society endangers our future. WW Norton \& Company.

Stroup, M. D. (2007). Economic freedom, democracy, and the quality of life. World Development, 35(1), 52-66.

Tang, C. H. H., \& Jang, S. S. (2009). The tourism-economy causality in the United States: A sub-industry level examination. Tourism Management, 30(4), 553-558.

Tewal, B., Mandey, S., \& Tumbel, A. (2017). Competitiveness and the increasing strategy of competitiveness in tourism sector of Ternate city, north Maluku province. Journal of Life Economics, 4(4), 11-32.

The Economic Times (2015). Available at:

https://economictimes.indiatimes.com/industry/healthcare/biotech/healthcare/indian-medicaltourism-industry-to-touch-8-billion-by-2020-grant-thornton/articleshow/49615898.cms [Online]. Retrieved on: 20 July, 2019.

Tučková, Z., \& Jurigová, Z. (2014). The meaning of tourism and tourism services in the V4 countries. GEORG, Zilina: 2014, s. 255.

United Nations Development Programme (1990). Human Development Report 1990. Available at: http://hdr.undp.org/en/humandev/ [Online]. Retrieved on 28 August, 2019. 
United Nations-World Tourism Organization (2018). Available at: https://www.eunwto.org/doi/pdf/10.18111/9789284419876 [Online]. Accessed on: 15 August, 2018.

Veal, A. J. (2017). Research methods for leisure and tourism. Pearson UK.

Wint, A. G. (1998). The role of government in enhancing the competitiveness of developing economies: Selective functional intervention in the Caribbean. International Journal of Public Sector Management, 11(4), 281-299.

Wolf, P. J. (1997). Why must we reinvent the federal government? Putting historical developmental claims to the test. Journal of Public Administration Research and Theory, 7(3), 353-388.

World Bank (2017). World Bank Open Data. Available at: https://data.worldbank.org/ [Online]. Retrieved on: 14 August, 2019.

World Economic Forum (2017). Available at: http://www.xinhuanet.com//english/201704/06/c_136187805.htm [Online]. Retrieved on: 14 August, 2019.

World Travel and Tourism Council (2015). Available at: https://www.wttc.org/about/mediacentre/press-releases/press-releases/2015/tourism-policy-council/ [Online]. Retrieved on: 22 July, 2019.

World Travel and Tourism Council (2018). Travel and Tourism Impact 2018 Pakistan. Available at: https://www.wttc.org/-/media/files/reports/economic-impactresearch/archived/countries-2018/pakistan2018.pdf [Online]. Retrieved on: 14 August, 2019.

World Travel and Tourism Council (2018). Travel and Tourism Impact 2018 China. Available at: https://www.chinatravelnews.com/images/201803/3e373c28a7e45f2b.pdf [Online]. Retrieved on: 15 August, 2019.

World Travel and Tourism Council (2018). Travel and Tourism Impact 2018 India. Available at: http://www.travelbizmonitor.com/Data-Analysis/travel-and-tourism-economic-impact2018-india-39836 [Online]. Retrieved on: 15 August, 2019.

Wright, P. M., McMahan, G. C., \& McWilliams, A. (1994). Human resources and sustained competitive advantage: a resource-based perspective. International journal of human resource management, 5(2), 301-326.

Xie, P. F. (2003). Managing aboriginal tourism in Hainan, China: Government perspectives. Annals of Leisure Research, 6(3), 278-299.

Yang, J., Ryan, C., \& Zhang, L. (2014). Sustaining culture and seeking a just destination: governments, power and tension-a life-cycle approach to analysing tourism development in an ethnic-inhabited scenic area in Xinjiang, China. Journal of Sustainable Tourism, 22(8), 1151-1174.

Yang, L., Wall, G., \& Smith, S. L. (2008). Ethnic tourism development: Chinese Government Perspectives. Annals of Tourism Research, 35(3), 751-771.

Yin, P. K. (2009). Case Study Research: Design and Methods. Sage Publication Inc.: Thousand Oaks, CA. 
Zerbe Jr, R. O., \& McCurdy, H. E. (1999). The failure of market failure. Journal of Policy Analysis and Management: The Journal of the Association for Public Policy Analysis and Management, 18(4), 558-578.

Zhong, L., Deng, J., \& Xiang, B. (2008). Tourism development and the tourism area lifecycle model: A case study of Zhangjiajie National Forest Park, China. Tourism Management, 29(5), 841-856. 